\title{
Motility, acrosome morphology and fertilizing capacity of cold-shocked hamster spermatozoa
}

\author{
Prudence Talbot \\ Department of Biology, University of California, Riverside, California 92521, U.S.A.
}

\begin{abstract}
Summary. When fresh epididymal spermatozoa were cold shocked for 10 or $30 \mathrm{~min}$, then warmed to $24^{\circ} \mathrm{C}$, sperm motility was normal, but cold shocking ejaculated or capacitated spermatozoa caused a significant decrease in the percentage of motile spermatozoa and, for capacitated spermatozoa, in the rate of motility. The acrosomes of motile fresh epididymal and ejaculated spermatozoa became crenulated after cold shock, and the percentage of spermatozoa with crenulated acrosomes increased with longer periods of cold shock and was higher when spermatozoa were cold shocked in serum than in saline. When epididymal spermatozoa were cold shocked after incubation for $4 \mathrm{~h}$ at $37^{\circ} \mathrm{C}$, the acrosomes on spermatozoa which had not undergone an acrosome reaction became swollen and elevated instead of crenulated. Epididymal spermatozoa which were cold shocked and then incubated for $4 \mathrm{~h}$ at $37^{\circ} \mathrm{C}$ exhibited acrosome reactions and activation of motility, but had reduced fertilizing capacity when tested in vitro. Spermatozoa incubated in serum and cold shocked were able to penetrate zone-free ova even though their tails had been bent through $180^{\circ}$. It is suggested that cold shock decreases the fertilizing capacity of hamster spermatozoa by interfering with the ability of spermatozoa to bind to and/or penetrate the zone pellucida.
\end{abstract}

\section{Introduction}

Cold shock is defined as the rapid cooling of spermatozoa or semen to temperatures just above $0^{\circ} \mathrm{C}$; for most species this results in irreversible loss of motility and fertilizing capacity (Mann, 1964). Hamster spermatozoa, however, tolerate cold shock remarkably well.

Although the acrosomes of hamster spermatozoa are morphologically altered by cold shock, such spermatozoa are able to undergo a normal acrosome reaction (loss of the acrosomal cap from highly motile spermatozoa) and activation of motility when warmed to $37^{\circ} \mathrm{C}$ and cultured in vitro (Talbot \& Franklin, 1976). The fertilizing capacity of such spermatozoa, however, has not been previously tested. This report extends our earlier observations on cold-shocked hamster spermatozoa in that the effects of cold shock on the motility and acrosome morphology of epididymal, ejaculated and serum-incubated spermatozoa are compared, and the capacity of cold-shocked spermatozoa to fertilize eggs in vivo and in vitro is examined.

\section{Materials and Methods}

The golden hamsters (Mesocricetus auratus) used were from the laboratory colony.

Collecton of spermatozoa. Spermatozoa from the cauda epididymidis were collected in 0.5 $\mathrm{ml}$ saline $(0.154 \mathrm{M}-\mathrm{NaCl})$ and further diluted to $2 \times 10^{8}$ cells $/ \mathrm{ml}$ immediately before use. Sperm concentration was measured turbidimetrically. Ejaculated spermatozoa were collected from 
lightly anaesthetized animals ( $5 \mathrm{mg}$ Nembutal/100 g body weight) by using a rectal probe and direct current generator (Keating, 1975) and were used without dilution. Epididymal and ejaculated spermatozoa were kept at $24^{\circ} \mathrm{C}$ under liquid paraffin oil until the start of an experiment (not more than $30 \mathrm{~min}$ after collection).

Cold shock. The effect of cold shock on motility and acrosome morphology of epididymal and ejaculated hamster spermatozoa was examined as follows. Droplets $(50 \mu \mathrm{l})$ of saline or heattreated $\left(60^{\circ} \mathrm{C}\right.$ for $\left.60 \mathrm{~min}\right)$ serum from human volunteers were placed in Falcon tissue-culture dishes and equilibrated at $5^{\circ} \mathrm{C}$. Control droplets were maintained at $37^{\circ} \mathrm{C}$. All inculations were carried out under liquid paraffin in an air atmosphere. Experiments were initiated by adding spermatozoa $(5 \mu \mathrm{l})$ into control $\left(37^{\circ} \mathrm{C}\right)$ and experimental $\left(5^{\circ} \mathrm{C}\right)$ media (final concentration $=10^{7}$ spermatozoa/ml). After incubation for 10 or $30 \mathrm{~min}$, samples were placed under Vaselinesupported coverslips, examined by phase-contrast microscopy and the percentages of motile spermatozoa (100 counted/sample) and spermatozoa with crenulated acrosomes (50 counted sample; see Talbot \& Franklin, 1976) were assessed. The quality of motility for most of the spermatozoa in a droplet was evaluated on a scale from 0 to 8 with increasing numbers corresponding to better cell vigour. A ranking of 8 was given to activated spermatozoa (see Yanagimachi, 1970).

The effect of cold shock on hamster spermatozoa which were induced to undergo capacitation and a normal acrosome reaction by incubation in heat-treated $\left(60^{\circ} \mathrm{C}\right.$ for $\left.60 \mathrm{~min}\right)$ human serum was also examined. Epididymal spermatozoa were incubated in $50 \mu \mathrm{l}$ heat-treated serum at $37^{\circ} \mathrm{C}$ for $4 \mathrm{~h}$, transferred to $24^{\circ} \mathrm{C}$ for $10 \mathrm{~min}$, then cold shocked by placing culture dishes at $5^{\circ} \mathrm{C}$. Motility and the condition of the acrosome were evaluated as described above after 10 and $30 \mathrm{~min}$ at $5^{\circ} \mathrm{C}$. The intermediate step $\left(24^{\circ} \mathrm{C}\right.$ for $\left.10 \mathrm{~min}\right)$ was included to prevent complete immobilization of the spermatozoa by cold shock. Photomicrographs were taken on a Reichert research microscope equipped with anoptral contrast optics.

In-vivo fertilization. Mature hamsters were induced to superovulate by injection of 25 i.u. PMSG on the morning of the vaginal discharge and 25 i.u. hCG on the 3rd evening after PMSG injection (Greenwald, 1962). Epididymal spermatozoa were collected as described above, placed in heat-treated serum, exposed to 24 or $5^{\circ} \mathrm{C}$ for $5 \mathrm{~min}$, pelleted by gentle centrifugation, and resuspended in fresh serum. After incubation at $37^{\circ} \mathrm{C}$ for $40-60 \mathrm{~min}, 0.1 \mathrm{ml}$ of the cold-shocked sperm suspension was injected into the ligated uterine horn of a female which had been induced to superovulate; control spermatozoa $\left(37^{\circ} \mathrm{C}\right)$ were injected into the contralateral horn. Ova were recovered from the oviducts $18 \mathrm{~h}$ later and examined for the presence of a sperm tail in the vitellus.

In-vitro fertilization. The fertilizing capacity of cold-shocked hamster spermatozoa was tested in vitro by using intact cumulus masses containing ova, cumulus-free ova, and zona pellucida-free ova. Cumulus masses were collected 12-14 h after the hCG injection from females induced to superovulate. Cumulus was added to cold-shocked or control spermatozoa (prepared as described for in-vivo fertilization) which had been incubated for $3 \mathrm{~h}$ at $37^{\circ} \mathrm{C}$ in heat-treated serum. Cumulus and spermatozoa were incubated together for $3 \mathrm{~h}$ then the ova were fixed in formalin and scored for penetration (the presence of spermatozoa in the perivitelline space or vitellus).

For experiments involving cumulus-free ova, cumulus masses were placed in droplets of Tyrode's solution containing hyaluronidase $(92 \mathrm{U} / \mathrm{ml})$ and agitated to disperse the ova. Free ova were washed three times in Tyrode's solution, added to spermatozoa, and scored for penetration $3 \mathrm{~h}$ later.

Zona pellucidas were removed from ova by incubating cumulus masses in Ham's F-10 medium containing hyaluronidase $(36 \mathrm{U} / \mathrm{ml})$ and trypsin $(20 \mathrm{U} / \mathrm{ml})$. After three washes in Ham's F-10 medium containing a trace of bovine serum albumin, zona-free ova were added to coldshocked or control spermatozoa, incubated for $50 \mathrm{~min}$ at $37^{\circ} \mathrm{C}$, fixed in formalin and scored for penetration.

Statistical comparisons were by the $\chi^{2}$ test. 


\section{Results}

The effect of cold shock on the motility and acrosome morphology of fresh epididymal and ejaculated hamster spermatozoa. The motility of epididymal hamster spermatozoa was not adversely affected when spermatozoa were cold shocked in either medium, but that of ejaculated spermatozoa was decreased significantly in both media (Table 1). Acrosomes of epididymal and ejaculated spermatozoa became crenulated after cold shoc\&. Maximum crenulation was induced by cold shock for $30 \mathrm{~min}$ in serum, but not in saline.

Table 1. The effects (mean \pm s.e.m. for 5 experiments) of cold shock on epididymal and ejaculated hamster spermatozoa

\begin{tabular}{|c|c|c|c|c|c|}
\hline \multicolumn{2}{|r|}{ Spermatozoa } & \multicolumn{2}{|c|}{ Controls $\left(37^{\circ} \mathrm{C}\right)$} & \multicolumn{2}{|c|}{ Cold shock $\left(5^{\circ} \mathrm{C}\right)$} \\
\hline Medium & Response $\dagger$ & $10 \mathrm{~min}$ & $30 \mathrm{~min}$ & $10 \mathrm{~min}$ & $30 \mathrm{~min}$ \\
\hline \multicolumn{6}{|c|}{ Epididymal spermatozoa } \\
\hline \multirow[t]{3}{*}{ Saline } & $\%$ Motile & $65 \cdot 4 \pm 3.0$ & $67 \cdot 3 \pm 4 \cdot 3$ & $64 \cdot 5 \pm 1 \cdot 5$ & $64.2 \pm 4.9$ \\
\hline & Motility rating* & $3.6 \pm 0.5$ & $3.6 \pm 0.9$ & $2.6 \pm 0.9$ & $2.8 \pm 0.8$ \\
\hline & $\%$ Crenulated acrosomes & $0 \cdot 0 \pm 0 \cdot 0$ & $0.8 \pm 1.1$ & $* 7.6 \pm 4.3$ & $* 34.0 \pm 8.9$ \\
\hline \multirow[t]{3}{*}{ Serum } & $\%$ Motile & $68 \cdot 2 \pm 2 \cdot 8$ & $68 \cdot 4 \pm 2 \cdot 1$ & $68 \cdot 0 \pm 2 \cdot 1$ & $65 \cdot 8 \pm 4 \cdot 8$ \\
\hline & Motility rating* & $3.0 \pm 0.0$ & $4.4 \pm 0.5$ & $3.0 \pm 0.7$ & $3.4 \pm 1 \cdot 1$ \\
\hline & $\%$ Crenulated acrosomes & $1 \cdot 2 \pm 1 \cdot 1$ & $1.6 \pm 2.6$ & ${ }^{*} 62.4 \pm 27.1$ & ${ }^{*} 96 \cdot 8 \pm 6 \cdot 1$ \\
\hline \multicolumn{6}{|c|}{ Ejaculated spermatozoa } \\
\hline \multirow[t]{3}{*}{ Saline } & $\%$ Motile & $58.8 \pm 2.5$ & $60 \cdot 0 \pm 2 \cdot 7$ & $* 49.8 \pm 3.7$ & $* 28.6 \pm 7.0$ \\
\hline & Motility rating* & $2.5 \pm 0.2$ & $2.8 \pm 0.2$ & $2.1 \pm 0.4$ & $0.9 \pm 0.1$ \\
\hline & $\%$ Crenulated acrosomes & $\overline{0}$ & $\overline{0}$ & $* 9.6 \pm 5.4$ & $* 36.8 \pm 9.9$ \\
\hline \multirow[t]{3}{*}{ Serum } & $\%$ Motile & $62 \cdot 0 \pm 5 \cdot 7$ & $59 \cdot 8 \pm 3 \cdot 3$ & $* 58.0 \pm 6.3$ & $* 52.0 \pm 6.3$ \\
\hline & Motility rating* & $3.3 \pm 0.7$ & $3.5 \pm 0.8$ & $3.4 \pm 1.7$ & $2.8 \pm 0.2$ \\
\hline & $\%$ Crenulated acrosomes & 0 & 0 & $* 32.5 \pm 6 \cdot 3$ & $* 87.2 \pm 7.9$ \\
\hline
\end{tabular}

* Values significantly different from the corresponding control value, $P<0.05$.

+ For $\%$ motile, 100 spermatozoa were counted in each experiment; motility rating was assessed on a $0-8$ scale (see text); for \% crenulated acrosomes 50 motile spermatozoa were counted in each experiment.

The effect of cold shock on epididymal spermatozoa incubated in serum before cold shock. Because serum batches vary in their ability to support acrosome reactions, batches in which a high or low percentage of reactions occurred were both used for comparison of the sensitivity of capacitated epididymal spermatozoa to cold shock. Epididymal spermatozoa which had undergone normal acrosome reactions in serum were very sensitive to cold shock (Table 2). The motility rating and percentage of motile spermatozoa decreased significantly even after exposure to $5^{\circ} \mathrm{C}$ for $10 \mathrm{~min}$. After $30 \mathrm{~min}$ of cold shock, the tails of motile spermatozoa became bent into loops resembling hairpins, but the spermatozoa still maintained some progressive motility. Heads and tails of many immobilized spermatozoa became separated.

When a serum batch in which most spermatozoa did not undergo an acrosome reaction, i.e. the acrosomal cap was intact on motile spermatozoa, was used, crenulation of the acrosome did not occur after cold shock (Table 2). The acrosomes became swollen and elevated (see Talbot $\&$ Franklin, 1976) and the motility rating was significantly lower than that of controls. Many sperm tails formed hairpin loops.

In-vivo fertilization with cold-shocked spermatozoa. In the control experiments with unshocked spermatozoa, 57 eggs were recovered from the uteri and $68 \%(38-100 \%$ in 3 experiments) were fertilized. The values for cold-shocked spermatozoa were 52 eggs recovered and $23 \%(0-75)$ fertilized $(P<0.01)$.

In-vitro fertilization with cold-shocked spermatozoa. The percentage of fertilized ova was decreased when cumulus masses were incubated with cold-shocked spermatozoa (Table 3 ). Swollen sperm nuclei were observed in the cytoplasm of $63.9 \%$ of the ova penetrated by coldshocked spermatozoa. In the other penetrated eggs, spermatozoa were present in the perivitelline $19: 35 \mathrm{PM}$ 
Table 2. The effects (mean \pm s.e.m. for 5 experiments) of cold shock on hamster epididymal spermatozoa preincubated for $4 \mathrm{~h}$ in heat-treated serum which supported or did not support acrosome reactions

\begin{tabular}{|c|c|c|c|c|}
\hline \multirow[b]{2}{*}{ Response $†$} & \multicolumn{2}{|c|}{ Controls $\left(24^{\circ} \mathrm{C}\right)$} & \multicolumn{2}{|c|}{ Cold shock $\left(5^{\circ} \mathrm{C}\right)$} \\
\hline & $10 \mathrm{~min}$ & $30 \mathrm{~min}$ & $10 \mathrm{~min}$ & $30 \mathrm{~min}$ \\
\hline \multicolumn{5}{|l|}{ Acrosome-reacted spermatozoa } \\
\hline$\%$ Motile & $62.8 \pm 1.4$ & $63 \cdot 1 \pm 1 \cdot 3$ & $* 50.2 \pm 5.7$ & $* 41 \cdot 8 \pm 5 \cdot 2$ \\
\hline Motility rating & $7.0 \pm 0.5$ & $6.8 \pm 0.5$ & $* 4.7 \pm 0.7$ & $* 3.0 \pm 0.4$ \\
\hline$\%$ Acrosome reacted & $82.5 \pm 5.5$ & $84.3 \pm 7.9$ & $78 \cdot 0 \pm 8 \cdot 6$ & $75 \cdot 7 \pm 11 \cdot 7$ \\
\hline \multicolumn{5}{|l|}{ Unreacted spermatozoa } \\
\hline Motility rating & $5.5 \pm 0.9$ & $5.7 \pm 0.9$ & $* 2.9 \pm 0.4$ & $* 1.9 \pm 0.3$ \\
\hline$\%$ Acrosome reacted & $10 \cdot 0 \pm 11 \cdot 1$ & $10 \cdot 0 \pm 11 \cdot 1$ & $1 \cdot 6 \pm 1 \cdot 3$ & $4 \cdot 0 \pm 2 \cdot 4$ \\
\hline$\%$ Crenulated acrosomes & $2 \cdot 6 \pm 2 \cdot 1$ & $2.7 \pm 1.6$ & $1.6 \pm 0.8$ & $3 \cdot 2 \pm 1 \cdot 5$ \\
\hline$\%$ Swollen acrosomes & $4.0 \pm 1.4$ & $7.0 \pm 4.6$ & $* 45.6 \pm 9.4$ & $* 59.2 \pm 7.7$ \\
\hline
\end{tabular}

* Values significantly different from the corresponding control value, $P<0.05$.

$\dagger$ See Table 1 . For $\%$ acrosome reacted and $\%$ swollen acrosomes, 50 motile spermatozoa were counted in each experiment.

space only. The distribution of supernumerary (70.2\%) and supplementary $(29.8 \%)$ spermatozoa was similar in control inseminations.

When fertilizing capacity was tested with cumulus-free ova, the percentage of those ova penetrated decreased with increasing lengths of cold shock (Table 3 ). The quality of the spermatozoa in incubation droplets was assessed under the dissecting microscope at $\times 100$ magnification immediately before addition of ova. Generally droplets from the 5- and 10-min experimental treatments were indistinguishable from controls, but spermatozoa cold shocked for 20 min sometimes appeared inferior (i.e. less reversal of agglutination, slightly slower swimming rate) than those in the 20 -min control or 5- and 10-min cold-shock groups. All droplets contained some activated spermatozoa. In several experiments, the binding of spermatozoa to the surface of the zona pellucida was noted. Control ova always had numerous spermatozoa $(>100)$ on the zona surface, but ova incubated with cold-shocked spermatozoa usually had

Table 3. The fertilization in vitro of hamster ova (cumulus free or intact) with cold-shocked spermatozoa after incubation for $3 \mathrm{~h}$

\begin{tabular}{|c|c|c|c|c|c|}
\hline $\begin{array}{l}\text { Pretreatment of } \\
\text { spermatozoa }\end{array}$ & $\begin{array}{c}\begin{array}{c}\text { No. of } \\
\text { experiments }\end{array}\end{array}$ & $\begin{array}{l}\text { Total } \\
\text { no. of } \\
\text { ova }\end{array}$ & $\begin{array}{l}\text { \% crenulated } \\
\text { acrosomes before } \\
\text { incubation } \\
\text { (range) }\end{array}$ & $\begin{array}{l}\text { \% acrosome-reacted } \\
\text { spermatozoa after } \\
\text { incubation } \\
\text { (range) }\end{array}$ & $\begin{array}{c}\% \text { of ova } \\
\text { penetrated } \\
\text { (range) }\end{array}$ \\
\hline \multicolumn{6}{|l|}{ Intact cumulus masses } \\
\hline $5 \mathrm{~min}$ at $24^{\circ} \mathrm{C}$ & 4 & 199 & $6(0-12)$ & $53(36-90)$ & $65(28-80)$ \\
\hline $5 \mathrm{~min}$ at $5^{\circ} \mathrm{C}$ & 4 & 208 & $59(50-70)$ & $34(16-60)$ & ${ }^{*} 17(0-39)$ \\
\hline $25 \mathrm{~min}$ at $5^{\circ} \mathrm{C}$ & 1 & 69 & -+ & $-\dagger$ & 0 \\
\hline \multicolumn{6}{|l|}{ Cumulus-free ova } \\
\hline $5 \mathrm{~min}$ at $24^{\circ} \mathrm{C}$ & 5 & 50 & 0 & $\begin{array}{c}26(8-40) \\
(3 \text { exps })\end{array}$ & 66 \\
\hline $5 \min$ at $5^{\circ} \mathrm{C}$ & 5 & 49 & $20(10-26)$ & $\begin{array}{c}30(14-48) \\
(3 \text { exps })\end{array}$ & *31 \\
\hline $10 \mathrm{~min}$ at $24^{\circ} \mathrm{C}$ & 3 & 61 & 0 & 26 (1 exp.) & 61 \\
\hline $10 \mathrm{~min}$ at $5^{\circ} \mathrm{C}$ & 3 & 24 & 74 (1 exp.) & 26 (1 exp.) & *8 \\
\hline 20 min at $24^{\circ} \mathrm{C}$ & 2 & 13 & $-\dagger$ & $-\dagger$ & 77 \\
\hline $20 \mathrm{~min}$ at $5^{\circ} \mathrm{C}$ & 2 & 13 & $-^{+}$ & $-\dagger$ & ${ }^{*} 0$ \\
\hline
\end{tabular}

* Values significantly different from the corresponding control value, $P<0.05$.

+ Data not available. 
Table 4. Penetration of zona-free hamster ova by cold-shocked epididymal spermatozoa preincubated with heat-treated serum for $4 \mathrm{~h}$

\begin{tabular}{lccccccc}
\hline & \multicolumn{3}{c}{ Controls (no preincubation) } & & \multicolumn{3}{c}{ Preincubation in serum } \\
\cline { 2 - 7 } \multicolumn{1}{c}{ Spermatozoa } & $\begin{array}{c}\text { No. of } \\
\text { exps }\end{array}$ & $\begin{array}{c}\text { Total } \\
\text { no. of } \\
\text { ova }\end{array}$ & $\begin{array}{c}\text { \% Penetrated } \\
\text { ova }\end{array}$ & & $\begin{array}{c}\text { No. of } \\
\text { exps }\end{array}$ & $\begin{array}{c}\text { Total } \\
\text { no. of } \\
\text { ova }\end{array}$ & $\begin{array}{c}\text { \% Penetrated } \\
\text { ova }\end{array}$ \\
\hline Fresh & 3 & 76 & 0 & 3 & 30 & 100 \\
Cold-shocked $\left(5 \min\right.$ at $\left.5^{\circ} \mathrm{C}\right)$ & 3 & 80 & 0 & 4 & 76 & 100 \\
\hline
\end{tabular}

fewer or even no $\left(5^{\circ} \mathrm{C}\right.$ for $\left.20 \mathrm{~min}\right)$ spermatozoa on the zona. The spermatozoa could be removed easily from control and experimental zonas by passage of ova in and out of a smallbore pipette.

Zona-free ova were not penetrated by fresh epididymal spermatozoa even in the control cultures but cold shock did not prevent penetration of ova by spermatozoa which had undergone capacitation, although these spermatozoa exhibited aberration in tail morphology and very poor motility (Table 4).

\section{Discussion}

The effect of cold shock on motility and acrosome morphology of hamster spermatozoa depends on the physiological state (epididymal, ejaculated or serum-incubated) of the cells, the composition of the supporting medium, and the duration of the cold-shock treatment. Capacitated spermatozoa (i.e. serum-incubated) are immobilized to a greater degree by cold shock than are fresh epididymal or ejaculated spermatozoa. Morita \& Chang (1970) noted that some of the secretions of the male reproductive tract sensitize epididymal hamster spermatozoa to cold shock and cause immobilization. The present study demonstrates that in an appropriate medium (serum) immobilization of hamster spermatozoa does not result from cold shock.

The acrosomes of hamster spermatozoa, like those of sheep (Walton, 1957), ram (Quinn, White \& Cleland, 1969; Jones \& Martin, 1973), boar (Boender, 1968; Pursel, Johnson \& Rampacek, 1972; Jones, 1973) and bull (Hancock, 1952) spermatozoa, are morphologically altered by cold shock. Cold shock produced crenulation of the acrosomal cap of fresh epididymal and ejaculated hamster spermatozoa. At the light microscope level, this change is morphologically similar to an intermediate stage of the normal acrosome reaction (Talbot \& Franklin, 1976), although it is not yet known whether the factors promoting crenulation are the same. Unlike those of fresh epididymal spermatozoa, the acrosomes of unreacted spermatozoa became swollen and elevated rather than crenulated when subjected to cold shock even after incubation in serum, indicating that the serum incubation had affected the acrosome in such a way as to preclude acrosomal crenulation. Therefore, even though viability and motility might appear normal after culture, the spermatozoa are unable to undergo normal acrosome reactions and their fertilizing ability would be limited.

Cold shock reduces fertilizing capacity, usually because it immobilizes spermatozoa (Mann, 1964). In the present study, epididymal spermatozoa were not immobilized after cold shock, although a progressive decrease in fertilizing capacity was observed with increased duration of cold shock. Reduction in fertilizing capacity was not caused by failure of the spermatozoa to undergo normal acrosome reactions, which are necessary for zona penetration (Austin, 1963), or activation of motility which accompanies capacitation in the hamster (Yanagimachi, 1970). Also, reduced fertilizing capacity was not due to failure of spermatozoa to reach the zona pellucida surface, as shown by the experiments with cumulus-free ova and the similar percent- 
age of fertilization in vivo. Cold shock did not inhibit fusion of the spermatozoa and vitellus when penetration of the zona pellucida was successful and zona-free ova were penetrated by cold-shocked capacitated spermatozoa in spite of highly aberrant tail morphology and motility. These observations, together with the reduced numbers of cold-shocked spermatozoa bound to the zona pellucida, suggest that the decreased fertilizing capacity of cold-shocked hamster spermatozoa is due to the failure of spermatozoa to bind to and/or penetrate the zona pellucida. Longer periods of cold shock could affect other events of fertilization, but in the present experimental conditions zona binding and/or penetration appeared to be most sensitive to cold shock.

The results of this study demonstrate the remarkable resistance of epididymal and ejaculated hamster spermatozoa to cold shock and the retention of some fertilizing capacity even after cold shock for 5 or 10 min. Factors which could explain this resistance are not yet known, but it is possible that the membranes of hamster spermatozoa are structurally different from those of other species because hamsters are hibernators. During hibernation the body temperature is reduced to $4-5^{\circ} \mathrm{C}$ and the factors which make hamster cell membranes able to withstand and function at these low temperatures (see Aloia \& Pengelley, 1978) could also enable hamster spermatozoa to tolerate cold shock better than spermatozoa from non-hibernators.

I am grateful to Dr. L. E. Franklin in whose laboratory portions of this work were done, to Dr R. J. Keating for assistance in collecting ejaculated spermatozoa and to Dr Gary Martin for suggestions regarding the manuscript. The work was supported by grants from The University of California and American Philosophical Society to P.T. and a grant from NIH to Dr L. E. Franklin.

\section{References}

Aloia, R.C. \& Pengelley, E.T. (1978) Lipids, membranes, and hibernation. In Chemical Zoology, Vol. XII, Eds M. Florkin \& B. T. Scheer. Academic Press, New York.

Austin, C.R. (1963) Acrosome loss from the rabbit spermatozoon in relation to entry into the egg. J. Reprod. Fert. 6, 313-314.

Boender, J. (1968) Morphological changes of the acrosome of boar spermatozoa during aging and cold shock. Proc. 6th Int. Congr. Anim. Reprod. \& A.I., Paris 2, 1217.

Greenwald, G.S. (1962) Analysis of superovulation in the adult hamster. Endocrinology 71, 378-389.

Hancock, J.C. (1952) The morphology of bull spermatozoa. J.exp. Biol. 29, 445.

Jones, R.C. (1973) Changes occurring in the head of boar spermatozoa: vesiculation or vacuolization of the acrosome? J. Reprod. Fert. 33, 113-118.

Jones, R.C. \& Martin, I.C.A. (1973) The effects of dilution, egg yolk and cooling to $5^{\circ} \mathrm{C}$ on the ultrastructure or ram spermatozoa. J. Reprod. Fert. 35, $311-320$.

Keating, R.J. (1975) Evaluation of the prosimian Galago senegalensis as a laboratory primate for in vitro studies on early gamete interactions. Ph.D thesis, University of Houston, Houston, Texas.

Mann, T. (1964) The Biochemistry of Semen and the Male Reproductive Tract. Methuen, London.

Morita, Z. \& Chang, M.C. (1970) The motility and aerobic metabolism of spermatozoa in laboratory animals with special reference to the effects of cold shock and the importance of calcium for the motility of hamster spermatozoa. Biol. Reprod. 3, 169-179.

Pursel, V.G., Johnson, L.A. \& Rampacek, G.B. (1972) Acrosome morphology of boar spermatozoa incubated before cold shock. J. Anim. Sci. 34, 278-283.

Quinn, P.J., White, I.G. \& Cleland, K.W. (1969) Chemical and ultrastructural changes in ram spermatozoa after washing, cold shock and freezing. $J$. Reprod. Fert. 18, 209-220.

Talbot, P. \& Franklin, L.E. (1976) Morphology and kinetics of the hamster sperm acrosome reaction. $J$. exp. Zool. 198, 163-176.

Walton, A. (1957) Cold shock of spermatozoa. Proc. $R$. Soc. $B$ 147, 508-509.

Yanagimachi, R. (1970) The movement of golden hamster spermatozoa before and after capacitation. J. Reprod. Fert. 23, 193-196.

Received 16 March 1978 